\title{
Problematyka zapasów według prawa bilansowego i międzynarodowych standardów rachunkowości
}

\section{Wprowadzenie}

Zapasy są niezagospodarowanymi dobrami rzeczowymi, utrzymywanymi przez przedsiębiorstwo celem użycia w przyszłości (dalsze przetwarzanie, proces montażu, utrzymanie wyposażenia przedsiębiorstwa, sprzedaż). Występują zwykle w formie surowców, półproduktów, części używanych w procesie produkcyjnym lub wyrobów gotowych i stanowią jedną z głównych pozycji aktywów obrotowych przedsiębiorstwa. Gospodarowanie zapasami można określić jako działalność mającą na celu utrzymanie zapasów na poziomie zapewniającym normalne funkcjonowanie przedsiębiorstwa, przy minimalizacji ich poziomu ze względu na koszty utrzymania, ograniczone przydziały materiałowe itp. Gospodarowanie zapasami można także zdefiniować jako zespół metod i środków umożliwiających optymalizację poziomu i struktury zapasów, przy utrzymaniu ciągłości zaopatrzenia procesów produkcji i obrotu towarowego. Działania te wymagają dobrego systemu ewidencji księgowej zdarzeń gospodarczych dotyczących zapasów (gospodarki magazynowej), co ułatwia racjonalne zarządzanie przedsiębiorstwem.

Celem opracowania jest przedstawienie rozwiązań ewidencyjnych, w tym zwłaszcza wyceny zapasów według przepisów ustawy o rachunkowości, wraz $\mathrm{z}$ określeniem konsekwencji ekonomicznych dla jednostki prowadzącej działalność, w tym także gospodarstw rolniczych. Scharakteryzowano ponadto najważniejsze zmiany dotyczące zapasów w ostatniej nowelizacji ustawy o rachunkowości, jak również przedstawiono rozwiązania w tym zakresie według Międzynarodowych Standardów Rachunkowości MSR-2 „Zapasy” oraz MSR-41 „Rolnictwo".

Do realizacji celów badawczych w opracowaniu przyjęto klasyfikację zapasów według ujęcia $\mathrm{w}$ bilansie majątkowym zawartym $\mathrm{w}$ ustawie o rachunkowości [2002], z podziałem na materiały, półprodukty i produkty w toku, pro- 
dukty gotowe $\mathrm{i}$ towary. Materiały stanowią nabyte od obcych kontrahentów i ewentualnie wyprodukowane przez własne komórki pomocnicze: surowce i inne materiały podstawowe, paliwa, materiały pomocnicze, opakowania, części zapasowe maszyn i urządzeń, które są przeznaczone do zużycia na potrzeby wszystkich rodzajów własnej działalności produkcyjnej. W skład materiałów wchodzą również odpadki, produkty uboczne i odzyski, powstałe w'toku produkcji lub innej działalności. W pozycji tej ujmuje się również wartość:

- materiałów odpisanych uprzednio w koszty bezpośrednio po zakupie, a niezużytych do końca roku obrotowego (na podstawie ich inwentaryzacji),

- materiałów w drodze, tj. tych, które jeszcze nie znajdują się fizycznie w posiadaniu jednostki gospodarczej, ale stanowiąjuż jej własność,

- inwentarza żywego, np. zakupionego do uboju.

Półprodukty i produkty w toku obejmują równowartość kosztów poniesionych na wytworzenie produktów (wyrobów i usług), które przeszły określone fazy produkcji, ale nie zostały zakończone - sa w toku realizacji. Produkcja w toku może występować w zakresie produkcji podstawowej i pomocniczej, obejmujących zarówno wytworzenie wyrobów, jak i świadczenie usług. W pozycji tej wykazuje się również wartość półproduktów, tj. tych produktów, które przeszły określone, zamknięte fazy produkcji, przeznaczone są do dalszego przerobu lub montażu i podlegają ewidencji ilościowo-wartościowej. Produkty gotowe obejmują wyroby gotowe, tj. takie produkty, które przeznaczone są do sprzedaży, nie podlegają dalszemu przerobowi w jednostce, w której zostały wytworzone oraz odpowiadaja określonym normom lub warunkom umownym, a także roboty i usługi zakończone, lecz jeszcze niesprzedane do końca okresu sprawozdawczego. Do produktów gotowych nie zalicza się:

- odpadów produkcyjnych - traktowanych jako zwrot materiałów zmniejszających koszt ich zużycia,

- materiałów wytworzonych na własne potrzeby - kwalifikowanych do materiałów,

- środków trwałych wytworzonych na własne potrzeby - ujmowanych w ramach majątku trwałego,

- towarów własnej produkcji, tj. wyrobów przekazanych własnym placówkom sprzedaży detalicznej oraz posiłków i wyrobów garmażeryjnych sprzedawanych w stołówkach i bufetach - ich wartość ujmuje się łącznie $\mathrm{z}$ towarami nabytymi.

Towary stanowią rzeczowe składniki majątkowe nabyte od obcych kontrahentów, z przeznaczeniem do dalszej odsprzedaży, bez poddawania ich procesowi produkcji. Towarami są również artykuły spożywcze przeznaczone do przetworzenia na posiłki w stołówkach i bufetach. W pozycji tej ujmuje się także wartość towarów w drodze, tj. tych, które jeszcze nie znajdują się fizycznie w posiadaniu jednostki, ale stanowiąjuż jej własność. 


\section{Zapasy w przepisach ustawy o rachunkowości}

Według ustawy o rachunkowości, przez rzeczowe aktywa obrotowe rozumie się materiały nabyte w celu zużycia na własne potrzeby, wytworzone lub przetworzone przez jednostkę produkty gotowe (wyroby i usługi) zdatne do sprzedaży lub $\mathrm{w}$ toku produkcji, półprodukty oraz towary nabyte w celu odprzedaży w stanie nieprzetworzonym. Rzeczowe składniki aktywów obrotowych wyceniane są nie rzadziej niż na dzień bilansowy (na ogół 31.12 bieżacego roku) według cen nabycia lub kosztów wytworzenia, nie wyższych od cen ich sprzedaży netto na dzień bilansowy. Cena nabycia to cena zakupu składnika aktywów, obejmująca kwotę należną sprzedającemu, bez podlegających odliczeniu podatku od towarów i usług oraz podatku akcyzowego, a w przypadku importu powiększona o obciążenia o charakterze publicznoprawnym oraz o koszty bezpośrednio zwiazzane z zakupem i przystosowaniem składnika aktywów do stanu zdatnego do używania lub wprowadzenia do obrotu, łącznie z kosztami transportu, jak też załadunku, wyładunku, składowania lub wprowadzenia do obrotu, a obniżona o rabaty, upusty oraz inne podobne zmniejszenia i odzyski. Jeżeli nie jest możliwe ustalenie ceny nabycia składnika aktywów, a w szczególności przyjętego nieodpłatnie, w tym w drodze darowizny, to jego wyceny dokonuje się według ceny sprzedaży takiego samego lub podobnego przedmiotu.

Według znowelizowanej ustawy o rachunkowości, koszty związane z zapasami są definiowane w sposób bardzo zbliżony jak w Międzynarodowym Standardzie Rachunkowości MSR-2 „Zapasy”1. Koszt wytworzenia produktu obejmuje koszty pozostające $\mathrm{w}$ bezpośrednim związku $\mathrm{z}$ danym produktem oraz uzasadnioną część kosztów pośrednio związanych z wytworzeniem tego produktu. Koszty bezpośrednie obejmują wartość zużytych materiałów bezpośrednich, koszty pozyskania i przetworzenia związane bezpośrednio z produkcją $\mathrm{i}$ inne koszty poniesione $\mathrm{w}$ związku $\mathrm{z}$ doprowadzeniem produktu do postaci i miejsca, w jakich produkt się znajduje w dniu wyceny. Do uzasadnionej, odpowiedniej do okresu wytwarzania produktu części kosztów pośrednich zalicza się zmienne pośrednie koszty produkcji oraz tę część stałych, pośrednich kosztów produkcji, które odpowiadają poziomowi tych kosztów przy normalnym wykorzystaniu zdolności produkcyjnych. Za poziom ten uznaje się przeciętna,

\footnotetext{
${ }^{1}$ Art. 10 ust. 3 ustawy o rachunkowości określa, że w sprawach nieuregulowanych przepisami ustawy, przyjmując zasadę (politykę) rachunkowości, jednostka może stosować krajowe standardy rachunkowości wydane przez uprawniony w myśl ustawy Komitet Standardów Rachunkowości. W przypadku braku odpowiedniego standardu krajowego może stosować Międzynarodowe Standardy Rachunkowości.
} 
zgodną z oczekiwaniami w typowych warunkach, wielkość produkcji za daną liczbę okresów lub sezonów, przy uwzględnieniu planowych remontów. Jeżeli nie jest możliwe ustalenie kosztu wytworzenia produktu, to jego wyceny dokonuje się według ceny sprzedaży netto takiego samego lub podobnego produktu, pomniejszonej o przeciętnie osiagany przy sprzedaży produktów zysk brutto ze sprzedaży, a w przypadku produktu w toku - także $\mathrm{z}$ uwzględnieniem stopnia jego przetworzenia. Do kosztów wytworzenia produktu nie zalicza się natomiast kosztów:

- będących konsekwencją niewykorzystanych zdolności produkcyjnych i strat produkcyjnych,

- ogólnego zarządu, które nie są związane z doprowadzaniem produktu do postaci i miejsca, w jakich produkt się znajduje na dzień wyceny,

- magazynowania wyrobów gotowych i półproduktów, chyba że poniesienie tych kosztów jest niezbędne w procesie produkcji,

- kosztów sprzedaży produktów.

Koszty te wpływają na wynik finansowy okresu sprawozdawczego, w którym zostały poniesione. W przypadkach uzasadnionych niezbędnym, długotrwałym przygotowaniem towaru lub produktu do sprzedaży bądź długim okresem wytwarzania produktu cenę nabycia lub koszt wytworzenia można zwiększyć o koszty obsługi zobowiązań zaciągniętych w celu finansowania zapasu towarów lub produktów w okresie ich przygotowania do sprzedaży bądź wytworzenia i związanych z nimi różnic kursowych, pomniejszone o przychody $\mathrm{z}$ tego tytułu.

Za cenę (wartość) sprzedaży netto składnika aktywów przyjmuje się możliwą do uzyskania na dzień bilansowy cenę jego sp̉rzedaży, bez podatku od towarów i usług i podatku akcyzowego, pomniejszoną o rabaty, upusty i inne podobne zmniejszenia oraz koszty związane $\mathrm{z}$ przystosowaniem składnika aktywów do sprzedaży i dokonaniem tej sprzedaży, a powiększoną o należną dotacje przedmiotową. Jeżeli nie jest możliwe ustalenie ceny sprzedaży netto danego składnika aktywów, to należy w inny sposób określić jego wartość godziwą ${ }^{2}$ na dzień bilansowy.

Kierownik jednostki, uwzględniając rodzaj i wartość poszczególnych grup rzeczowych składników aktywów obrotowych posiadanych przez jednostkę, podejmuje decyzję o stosowaniu jednej z następujących metod prowadzenia kont ksiąg pomocniczych dla tych grup składników:

\footnotetext{
${ }^{2}$ Za wartość godziwą przyjmuje się kwotę, za jaką dany składnik aktywów mógłby zostać wymieniony, a zobowiazanie uregulowane na warunkach transakcji rynkowej między zainteresowanymi i dobrze poinformowanymi, niepowiązanymi ze sobą stronami.
} 
- ewidencję ilościowo-wartościowa, w której dla każdego składnika ujmuje się obroty i stany $w$ jednostkach naturalnych i pieniężnych,

- ewidencje ilościową obrotów i stanów, prowadzoną dla poszczególnych składników lub ich jednorodnych grup wyłącznie w jednostkach naturalnych. Wartość stanu wycenia się przynajmniej na koniec okresu sprawozdawczego, za który następują rozliczenia $\mathrm{z}$ budżetem $\mathrm{z}$ tytułu podatku dochodowego, dokonane na podstawie danych rzeczywistych,

- ewidencje wartościową obrotów i stanów towarów oraz opakowań, prowadzoną dla punktów obrotu detalicznego lub miejsc składowania, której przedmiotem zapisów są tylko przychody, rozchody i stany całego zapasu,

- odpisywania w koszty wartości materiałów i towarów na dzień ich zakupu lub produktów gotowych w momencie ich wytworzenia, połączone $\mathrm{z}$ ustalaniem stanu tych składników aktywów i jego wyceny oraz korekty kosztów o wartość tego stanu, nie później niż na dzień bilansowy.

Trwała utrata wartości zachodzi wtedy, gdy istnieje duże prawdopodobieństwo, że kontrolowany przez jednostkę składnik aktywów (np. zapasy) nie przyniesie w przyszłości w znaczącej części lub w całości przewidywanych korzyści ekonomicznych. Uzasadnia to dokonanie odpisu aktualizującego, doprowadzającego wartość składnika aktywów wynikającą z ksiag rachunkowych do ceny sprzedaży netto, a w przypadku jej braku - do ustalonej w inny sposób wartości godziwej.

Jednostki mogą wyceniać:

- materiały i towary - w cenach zakupu,

- produkty w toku produkcji - w wysokości bezpośrednich kosztów wytworzenia lub tylko materiałów bezpośrednich bądź nie wyceniać ich w ogóle, jeżeli nie zniekształca to stanu aktywów oraz wyniku finansowego jednostki. Zasady te nie moga być stosowane do produkcji o przewidywanym czasie wykonania dłuższym niż 3 miesiące, przeznaczonej do sprzedaży lub na rzecz środków trwałych w budowie jednostki. Nie dotyczy to jednak produkcji rolnej.

$\mathrm{Na}$ poziom wartości stanu zapasów (materiałów, towarów, produktów) w bilansie ma wpływ wybór określonej metody ich wyceny, przepisy bowiem dopuszczają stosowanie następujących metod:

- metoda wyceny przeciętnej (średnioważonej) z uwzględnieniem cen zapasów początkowych, tzn. w bilansie wystapią zapasy po cenie (koszcie) przeciętnej (średnioważonej),

- metoda „pierwsze weszło - pierwsze wyszło", tzn. w bilansie wystapią zapasy po cenie (koszcie) ostatniej,

- metoda „ostatnie weszło - pierwsze wyszło", tzn. w bilansie wystapią zapasy po cenie (koszcie) najwcześniejszej, 
- metoda szczegółowej identyfikacji rzeczywistych cen (kosztów) tych składników majątkowych, które dotyczą ściśle określonych przedsięwzięć, niezależnie od daty ich zakupu lub wytworzenia.

Składniki rzeczowych aktywów obrotowych mogą być na dzień nabycia lub wytworzenia ujmowane $w$ księgach rachunkowych w cenach przyjętych do ewidencji, z uwzględnieniem różnic między tymi cenami a rzeczywistymi cenami ich nabycia albo zakupu, albo kosztami wytworzenia. Na dzień bilansowy wartość składników rzeczowych aktywów obrotowych, wyrażoną w cenach ewidencyjnych, doprowadza się do poziomu określonego w ustawie o rachunkowości w art. 28 ust. 1 pkt 6 lub w art. 34 ust. 1. Nie dotyczy to produktów gotowych, produktów w toku i półproduktów, jeżeli do ich ewidencji stosuje się koszty planowane, w tym normatywne, różnice zaś między planowanymi a rzeczywistymi kosztami wytworzenia są nieznaczne. Stosowane do wyceny na dzień bilansowy ceny nabycia albo zakupu, albo planowane koszty wytworzenia nie mogą być wyższe od cen sprzedaży netto tych składników.

Odpisy aktualizujące wartość rzeczowych składników aktywów obrotowych dokonane $\mathrm{w}$ związku $\mathrm{z}$ utratą ich wartości oraz wynikające $\mathrm{z}$ wyceny według cen sprzedaży netto zamiast według cen nabycia albo zakupu, albo kosztów wytworzenia - zalicza się odpowiednio do pozostałych kosztów operacyjnych, kosztów wytworzenia sprzedanych produktów lub kosztów sprzedaży.

Znowelizowana ustawa o rachunkowości wprowadziła wiele zmian o charakterze formalnym i merytorycznym w zakresie ustalenia wartości bilansowej rzeczowych składników aktywów obrotowych, co może mieć wpływ na obliczanie wskaźników dotyczących tego obszaru majątku. Utrzymano jednak generalną zasadę wyceny tego typu aktywów, że jest ona dokonywana wedhug cen nabycia lub kosztów wytworzenia nie wyższych od cen ich sprzedaży netto na dzień bilansowy [Ustawa o rachunkowości 2002, art. 28 ust. 1, pkt 6].

Nowy zapis w art. 17 ust. 2 ustawy o rachunkowości wprowadza zmianę w zakresie wyceny zapasów rzeczowych składników aktywów obrotowych posiadanych przez jednostkę, gdy wybiera ona tylko ewidencję ilościową obrotów i sald, prowadzoną dla poszczególnych składników lub ich jednorodnych grup wyłącznie w jednostkach naturalnych. Obecny zapis oznacza w praktyce obowiązek dokonania wyceny przynajmniej na koniec okresu sprawozdawczego, za który następują rozliczenia $\mathrm{z}$ budżetem $\mathrm{z}$ tytułu podatku dochodowego na podstawie danych rzeczywistych. Powiazzano więc konieczność wyceny tego rodzaju aktywów z ustawą o podatku dochodowym [2000]. Jeżeli jednostka wybierze ewidencję zapasów w formie „odpisywania w koszty wartości materiałów i towarów na dzień ich zakupu lub produktów gotowych w momencie ich wytworzenia", to ustala stan tych składników aktywów i dokonuje wyceny oraz korekty kosztów o wartość tego stanu, nie później niż na 
dzień bilansowy. Pominięto zapis, że ustalenie stanu zapasów musi nastapić drogą spisu z natury na koniec każdego kwartału, a przy produkcji rolnej - na dzień bilansowy. Zmiana ta umożliwia jednostkom prowadzącym ewidencję ilościową przejście na półroczną, a nawet roczną inwentaryzację materiałów i towarów, których wartość jest odpisywana w koszty na dzień zakupu, a wyrobów gotowych w koszty - w momencie ich wytworzenia [Buk 2003].

Spośród wszystkich rodzajów rzeczowych składników aktywów obrotowych największe zmiany nastapiły w zakresie wyceny produktów, a wiążą się one $\mathrm{z}$ innym sposobem ustalania kosztów ich wytworzenia. Produktami są wyroby gotowe wyprodukowane lub będące w trakcie wytwarzania przez podmiot gospodarczy (przedsiębiorstwo rolnicze) oraz przeznaczone na sprzedaż. W przypadku jednostki świadczącej usługi do zapasów produktów zalicza się wydatki poniesione na realizację usług, w odniesieniu do których jednostka gospodarcza nie ujęła jeszcze odnośnych przychodów. Koszty (wartość początkowa) zapasów dotyczące tych pozycji, które nie są wzajemnie wymienialne, należy ustalić z zastosowaniem metody szczegółowej ich identyfikacji. Oznacza to, że konkretny koszt (wartość początkowa) należy przyporządkować do określonej pozycji zapasów. Koszt zapasów powinien obejmować wszystkie koszty związane $\mathrm{z}$ ich nabyciem, przetworzeniem oraz inne koszty poniesione podczas doprowadzania zapasów do ich aktualnego miejsca i stanu. Taka szczegółowa identyfikacja kosztu nie jest konieczna przy występowaniu dużej ilości pozycji zapasów wzajemnie wymienialnych.

\section{Wybrane rozwiązania ewidencji księgowej w rolnictwie}

Prowadzenie ewidencji księgowej może mieć mniej lub bardziej rozbudowaną postać. Forma ewidencji, zakres i stopień szczegółowości zapisów uzależnione są od potrzeb i możliwości zarządzającego gospodarstwem rolniczym [Bernacki, Wasilewski 1995]. Prowadzenie księgowości w rolnictwie powinno odzwierciedlać wszystkie procesy gospodarcze, jednak ujęcie księgowe wszystkich elementów cząstkowych występujących podczas procesów produkcyjnych $w$ rolnictwie stwarza problemy ze względu na różnorodność cyklów produkcyjnych i występujący obrót wewnętrzny. Do 1956 r. w przedsiębiorstwach rolniczych prowadzono księgowość podwójna, której zadaniem było ujmowanie całego obrotu wewnętrznego i prowadzenie kalkulacji rolniczych. Ani sposób prowadzonych kalkulacji, ani rejestrowanie obrotów w praktyce nie zdały egzaminu [Manteuffel 1964], decyzje produkcyjne bowiem zapadały poza danymi z działów rachunkowości. 
W celu pokonania tych problemów w 1957 r. w księgowości przedsiębiorstw rolniczych wprowadzono pewne uproszczenia, które zachowały się do dzisiaj $^{3}$. Zaprzestano księgowania obrotów wewnętrznych, co przyczyniło się do wyeliminowania wielu uciążliwych rozliczeń ilościowo-wartościowych. Zakup produktów, materiałów i usług, a także wynagrodzenia księguje się bezpośrednio na koncie „koszty”, a sprzedaż produktów i usług na koncie „przychody". Jako koszt traktuje się każdy wydatek w momencie jego poniesienia, a nie w momencie zużycia tego środka. Na przykład, zakup środków chemicznych traktuje się jako koszt, tak jakby od razu środki te były zużyte na polu pod uprawiane rośliny. Podobnie nie księguje się przychodów uzyskanych z produkcji, a jedynie przychody $z$ ich sprzedaży. Na koniec okresu sprawozdawczego koszty i przychody są przenoszone na konto wynikowe. Zaprzestano również prowadzenia na bieżąco ewidencji wartościowej w księdze głównej stanów i zmian zapasów, materiałów, produktów i inwentarza żywego [Goraj, Mańko, Sass, Wyszkowska 2004]. Prowadzi się jednak ewidencję ilościową tych składników majątku w księgach gospodarczych, to znaczy w księdze magazynowej i inwentarza żywego. Konto „zapasy” służące do wartościowej ewidencji stanu zapasów produktów i inwentarza żywego jest otwierane na początku roku, a w ciagu roku obrachunkowego nie funkcjonuje. Sprawia to, że bieżąca analiza stanów zapasów (np. miesięcznych, kwartalnych) jest niemożliwa albo bardzo utrudniona. Pod koniec roku, po wykonaniu inwentaryzacji i ustaleniu wartości stanów zapasów, materiałów, produktów i inwentarza żywego, sq̨ ustalane różnice między stanem początkowym i końcowym w tych grupach składników majątku. Ustalone różnice są księgowane na koncie „zapasy” w korespondencji $\mathrm{z}$ kontem wynikowym, uruchomionym ra czas obliczania wyniku finansowego i dokonywania przeksięgowań. Ostateczny wynik ustalany na końcu roku pod-

\footnotetext{
${ }^{3}$ Uproszczenia $w$ dokumentacji i w księgowości finansowej oszczędzają dużo pracy. Powinny jednak łączyć się $z$ prowadzeniem bardzo starannych i dokładnych zapisów $w$ księgowości ilościowej, która pozostaje jako jedyne narzędzie dokumentujące zdarzenia gospodarcze. Negatywne znaczenie ma często stosowane uproszczenie, polegające na braku wyceny produkcji w toku. Przy takiej zasadzie wyniki finansowe dwóch kolejnych lat moga ulegać znacznym zniekształceniom, ponieważ ponoszone koszty obciążają dany rok, a osiągane przychody wpływają na zysk naștępnego roku. Dotyczy to jednak głównie sytuacji znacznych zmian w strukturze produkcji rolniczej, zwłaszcza roślinnej. W przeszłości, kiedy w państwowych gospodarstwach rolnych obowiązywał rok obrachunkowy kończący się 30 czerwca, ustalenie wartości produkcji $\mathrm{w}$ toku, w szczególności tej na polach, było bardzo trudne. Istniała duża możliwość podawania wartości niewłaściwych, a obowiązujący obecnie rok kalendarzowy nie rozwiązał tego problemu. Zakładając jednak kontynuację działalności gospodarstw w dotychczasowym typie rolniczym oraz sposobie organizacji produkcji, można przyjać, że produkcja niezakończona nie różnicuje w sposób istotny wyników oceny ekonomiczno-finansowej gospodarstw rolniczych.
} 
czas przeksięgowań jest różnicą między saldem konta „przychody” i saldem konta „koszty”, z uwzględnieniem stwierdzonych różnic inwentaryzacyjnych zaksięgowanych na koncie ,zapasy". Termin i częstotliwość inwentaryzacji uważa się za dotrzymane, jeżeli inwentaryzację zapasów materiałów, towarów, produktów gotowych i półproduktów znajdujących się w strzeżonych składowiskach i objętych ewidencją ilościowo-wartościową przeprowadzono raz w ciagu 2 lat [Ustawa o rachunkowości 2002].

Dużym problemem i jednocześnie stosowanym uproszczeniem w księgowości przedsiębiorstw rolniczych jest klasyfikowanie inwentarza żywego. Wielokrotnie wprowadzano zmiany przy rejestrowaniu tego składnika majątku. Obecnie cały inwentarz żywy poddawany jest na koniec roku inwenturze, ale w bilansie stado podstawowe wliczane jest do aktywów trwałych, a stado obrotowe do aktywów obrotowych [Bernacki, Wasilewski 1998]. Zaproponowana klasyfikacja powoduje w praktyce konieczność okresowego przekwalifikowania zwierząt wchodzących w skład aktywów obrotowych do środków trwałych, co nastapi zwłaszcza w przypadku ich dojrzewania. Staną się one wówczas zwierzętami hodowlano-użytkowymi. Może też wystapić sytuacja odwrotna, gdy zwierzęta hodowlane przeznaczy się do tuczu i opasu. Przekwalifikowania te powinny następować tylko w jednostkach prowadzących typową działalność rolną lub o podobnym charakterze, np. w ośrodkach hodowli zarodowej. Zwierzęta zakupione $\mathrm{z}$ przeznaczeniem do uboju na mięso lub wyroby masarskie we własnych zakładach oraz przejęte $w$ tym celu $z$ własnego chowu powinny być zaliczane do materiałów, natomiast $w$ razie prowadzenia przez jednostkę obrotu handlowego zwierzęta powinny być zaliczane do towarów. Takie podejście nie ma wpływu na ogólną sumę składników aktywów, ale przy obliczaniu różnych wskaźników jest ważne, ponieważ wpływa na ich poziom [Wasilewski 2003b]. Dotyczy to zwłaszcza wskaźnika płynności ogólnej, przy obliczaniu którego inwentarz obrotowy jest często znaczącym składnikiem aktywów obrotowych. W gospodarstwach rolniczych z formuły obliczania tego wskaźnika wynika na ogół (relacja aktywów obrotowych do zobowiązań bieżących) jego duża wielkość, znacznie przekraczająca zalecany dotychczas w przedsiębiorstwach pozarolniczych poziom. Obrotowy inwentarz żywy jest zatem składnikiem podwyższającym płynność finansową gospodarstwa. W sytuacji zasadniczych problemów z płynnością pieniężną może być sprzedany, bez względu na etap technologiczny produkcji. W okresie normalnego funkcjonowania gospodarstwa obrotowy inwentarz żywy jest pewnym rodzajem gwarancji zachowania płynności, chociaż sprzedaż przed momentem dojrzałości technologicznej może być nieracjonalna [Wasilewski 2004]. 


\section{Unormowania międzynarodowe w zakresie ewidencji zapasów}

Przesłanką unormowań prawnych zagadnień dotyczących zapasów, poza ustawą o rachunkowości, są.Międzynarodowe Standardy Rachunkowości (MSR). Celem MSR-2 „Zapasy" jest uregulowanie sposobu księgowania zapasów zgodnie z systemem kosztów historycznych. Najważniejszym zagadnieniem w księgowaniu zapasów jest kwota ceny nabycia lub kosztu wytworzenia zapasów, którą należy ująć jako składnik aktywów i przenieść na następne okresy, aż do ujęcia odnośnych przychodów. W standardzie posłużono się terminami o zróżnicowanym znaczeniu. Stwierdzono, że zapasy są to aktywa [MSSF 2004]:

- przeznaczone do sprzedaży w toku zwykłej działalności gospodarczej,

- będacee w trakcie produkcji przeznaczonej na sprzedaż lub,

- mające postać materiałów lub dostaw surowców zużywanych w procesie produkcyjnym lub $w$ trakcie świadczenia usług.

Zgodnie z MSR-41 „Rolnictwo", zapasy obejmujace produkty rolnicze, zebrane/pozyskane. $\mathrm{z}$ aktywów biologicznych należących do jednostki gospodarczej, należy wyceniać $w$ momencie początkowego ujęcia $w$ wartości godziwej, pomniejszonej o szacunkowe koszty związane ze sprzedaża, ponoszone do dnia zbioru/pozyskania produktów [Wasilewski 2003a]. Na zapasy składają się dobra zakupione i przeznaczone do odsprzedaży, na przykład towary zakupione przez jednostkę handlu detalicznego w celu ich odsprzedaży, lub grunty i inne nieruchomości przeznaczone do odsprzedaży [MSSF 2004]. Należy podkreślić jednak, że jest to specyficzna forma zapasu, która w działalności rolniczej na ogół nie występuje. Do zapasów zalicza się także produkty gotowe wyprodukowane lub będące $\mathrm{w}$ trakcie wytwarzania ich przez jednostkę gospodarcza, łącznie z materiałami i surowcami oczekującymi na wykorzystanie w procesie produkcji. W przypadku jednostki gospodarczej świadczącej usługi do zapasów zalicza się wydatki poniesione na realizację usług, w odniesieniu do których jednostka gospodarcza nie ujęła jeszcze odnośnych przychodów.

Zapasy należy wyceniać w wysokości kosztu (wartości początkowej) lub według ceny sprzedaży netto, w zależności od tego, która z kwot jest niższa. Według MSR-2 „Zapasy”, koszt (wartość początkowa) zapasów powinien składać się ze wszystkich kosztów nabycia, kosztów przetworzenia oraz innych kosztów poniesionych $w$ trakcie doprowadzania zapasów do ich aktualnego miejsca i stanu. Cena nabycia zapasów składa się z ceny zakupu, ceł importowych i pozostałych podatków (innych niż te możliwe do odzyskania w okresie późniejszym przez jednostkę gospodarczą od urzędów skarbowych), kosztów 
transportu, załadunku i wyładunku oraz innych kosztów dających się bezpośrednio przyporządkować do pozyskania wyrobów gotowych, materiałów i usług. Przy określaniu ceny nabycia odejmuje się upusty, rabaty handlowe $\mathrm{i}$ inne podobne pozycje. Do ceny nabycia można zaliczyć różnice kursowe wynikające bezpośrednio $\mathrm{z}$ faktu nabycia zapasów zafakturowanych $\mathrm{w}$ walucie obcej, na co w rzadkich okolicznościach zezwala w dopuszczonym podejściu alternatywnym MSR-21 „Skutki zmian kursów wymiany walut obcych". Różnice kursowe sq̨ ograniczone do różnic będących skutkiem ostrej dewaluacji lub deprecjacji waluty, przed którą nie istnieją praktyczne środki zabezpieczenia się, co wpływa na zobowiązania, których nie można uregulować i wynikają one bezpośrednio $\mathrm{z}$ niedawnego nabycia zapasów. W pewnych nielicznych okolicznościach koszty finansowania zewnętrznego zalicza się do kosztu (wartości początkowej) zapasów. Okoliczności te zostały określone w dopuszczonym podejściu alternatywnym, zawartym w MSR-23 „Koszty finansowania zewnętrznego".

Dla ułatwienia można stosować techniki wyceny kosztu (wartości początkowej) zapasów, takie jak metoda kosztu standardowego czy metoda wyceny według cen detalicznych, jeżeli w wyniku ich zastosowania otrzymuje się przybliżoną kwotę kosztu (wartości początkowej). Metoda kosztu standardowego opiera się na normalnym poziomie zużycia materiałów i surowców, robocizny oraz wydajności i wykorzystania zdolności produkcyjnej. Koszty standardowe są systematycznie analizowane $\mathrm{i}$ - jeśli to konieczne - aktualizowane w świetle bieżących warunków. Metoda wyceny według cen detalicznych jest często wykorzystywana w jednostkach handlu detalicznego do wyceny dużej ilości szybko rotujących i mających podobne marże pozycji zapasów, dla których stosowanie innych metod ustalania ich kosztu (wartości początkowej) niż metoda wyceny według cen detalicznych jest niewykonalne ze względów praktycznych. Koszt (wartość początkowa) zapasów określa się, redukując wartość sprzedaży zapasów o odpowiedni procent marży. Przy stosowaniu określonego procentu marży bierze się pod uwage zapasy, których cena została obniżona poniżej ich oryginalnej ceny sprzedaży. Często stosuje się średni procent marży brutto dla poszczególnych jednostek (sklepów/działów) handlu detalicznego [MSSF 2004].

Koszt (wartość początkowa) zapasów może nie być możliwy do odzyskania, jeżeli zapasy zostały uszkodzone, utraciły całkowicie lub częściowo przydatność lub jeśli spadły ich ceny sprzedaży. Brak możliwości odzyskania kosztu (wartości początkowej) zapasów może także wynikać ze wzrostu szacowanych kosztów przygotowania sprzedaży lub szacowanych kosztów niezbędnych do doprowadzenia sprzedaży do skutku. Stosowana praktyka odpisywania wartości zapasów poniżej ich kosztu (wartości początkowej) do po- 
ziomu ceny sprzedaży netto jest zgodna $\mathrm{z}$ poglądem, że aktywów nie należy ujmować w kwotach przewyższających kwoty, których osiągnięcia oczekuje się z tytułu ich sprzedaży lub wykorzystania. Odpisanie wartości zapasów do poziomu ich ceny sprzedaży netto odbywa się na zasadzie odpisów indywidualnych. W niektórych okolicznościach odpowiednie może jednak być pogrupowanie podobnych lub powiazzanych ze sobą pozycji zapasów. Może to mieć miejsce $w$ przypadku pozycji zapasów związanych z produktami pochodzącymi $\mathrm{z}$ tej samej linii produkcyjnej, mających podobne przeznaczenie oraz zastosowanie końcowe, wyprodukowanych $i$ sprzedawanych $w$ tym samym regionie geograficznym oraz niedających się w praktyce oszacować w oderwaniu od innych pozycji pochodzących z tej samej linii produkcyjnej. Nieodpowiednie jest odpisywanie wartości zapasów na podstawie klasyfikacji zapasów, na przykład wyrobów gotowych lub też wszystkich zapasów poszczególnych segmentów branżowych lub geograficznych. Jednostki usługowe zazwyczaj kumulują koszty każdej usługi, za którą zostanie ustalona odrębna cena. Dlatego też każdą tego rodzaju usługę traktuje się jako odrębną pozycję.

Szacunki ceny sprzedaży netto opieraja się na najbardziej wiarygodnych dowodach dostępnych w czasie ich sporządzania co do przewidywanej kwoty, możliwej do zrealizowania $\mathrm{z}$ tytułu sprzedaży zapasów. Szacunki te uwzględniają wahania cen oraz kosztu (wartości początkowej), odnoszące się bezpośrednio do zdarzeń mających miejsce po zakończeniu okresu $\mathrm{w}$ zakresie, w jakim zdarzenia te potwierdzają warunki istniejące na końcu okresu. Przy szacowaniu ceny sprzedaży netto bierze się także pod uwagę przeznaczenie zapasów. Na przykład, cena sprzedaży netto pewnej ilości zapasów mających służyć zrealizowaniu wiążących umów sprzedaży lub świadczeniu usług opiera się na cenie wynikającej z umowy. Jeżeli umowy sprzedaży są zawarte na ilości mniejsze niż pozostajace $w$ zapasach, to cena sprzedaży netto pozostałej nadwyżki zapasów opiera się na ogólnych cenach sprzedaży. Straty warunkowe poniesione na wiazżących umowach sprzedaży z tytułu nadwyżki ilości pozostałych zapasów oraz straty na wiążących umowach zakupu ujmuje się zgodnie z MSR-10 „Zdarzenia warunkowe oraz zdarzenia następujące po dniu bilansowym".

Wartości materiałów i innych surowców przeznaczonych do wykorzystania w procesie produkcji zapasów nie odpisuje się do kwoty niższej od kosztu (wartości początkowej), jeżeli oczekuje się, że wyroby gotowe, do produkcji których zostaną wykorzystane, będą sprzedane w wysokości kosztu (wartości początkowej) lub powyżej kosztu (wartości początkowej). Jeżeli jednak spadek cen materiałów wskazuje na to, że koszt (wartość poczatkowa) wyrobów gotowych będzie wyższy od ceny sprzedaży netto, to wtedy wartość materiałów odpisuje się do poziomu ceny sprzedaży netto. W takich okolicznościach 
koszty odtworzenia materiałów mogą stanowić najlepszy dostępny sposób wyceny ich ceny sprzedaży netto. W każdym kolejnym okresie dokonuje się nowego oszacowania tej ceny. Jeżeli nie istnieją już okoliczności, które uprzednio spowodowały odpisanie wartości zapasów poniżej wysokości kosztu (wartości początkowej), odpisaną kwotę eliminuje się, tak aby nowa wartość bilansowa równała się kwocie kosztu (wartości początkowej) lub zaktualizowanej cenie sprzedaży netto, w zależności od tego, która $\mathrm{z}$ tych kwot jest niższa. Ma to miejsce na przykład wtedy, gdy pozycja zapasów, którą ujmuje się w kwocie ceny sprzedaży netto ze względu na spadek jej ceny sprzedaży, w kolejnym okresie jest nadal w posiadaniu jednostki, a cena jej sprzedaży wzrosła.

\section{Wnioski}

W opracowaniu przedstawiono rozwiązania ewidencyjne, w tym zwłaszcza zasady wyceny zapasów według przepisów ustawy o rachunkowości, jak również scharakteryzowano rozwiązania w tym zakresie wedhug Międzynarodowych Standardów Rachunkowości MSR-2 „Zapasy” oraz MSR-41 „Rolnictwo". Na podstawie przeprowadzonych analiz sformułowano następujące wnioski końcowe.

1. Wprowadzona w życie znowelizowana ustawa o rachunkowości wymaga od księgowych i analityków finansowych identyfikowania ponoszonych kosztów w związku z prowadzoną działalnością z punktu widzenia ich celowości, analizowania efektywności przedsięwzięć oraz prezentowania informacji w sprawozdaniach finansowych bardziej odpowiadających treści ekonomicznej zdarzeń gospodarczych. Obowiązujące aktualnie zasady ustalania kosztu wytworzenia produktu ograniczają aktywowanie nieuzasadnionych kosztów na tworzone zapasy produktów, przez co obraz sytuacji majątkowej jednostki gospodarczej jest bardziej realny. Ponadto, wszystkie koszty nieuzasadnione i towarzyszące powstawaniu i utrzymywaniu zapasów produktów wpływają na wynik finansowy tego okresu, w którym te koszty są poniesione.

2. Zarówno rozwiązania ewidencyjne, jak i zasady wyceny zapasów mają ścisłe uregulowania zawarte $w$ ustawie o rachunkowości, w bardzo dużym stopniu zbieżne z rozwiązaniami przyjętymi w MSR-2 „Zapasy”. Wprowadzenie MSR-41 „Rolnictwo" umożliwiło większe sprecyzowanie rozwiązań dotyczących zapasów w gospodarstwach rolniczych. Rolnictwo, z racji specyfiki produkcji o charakterze biologicznym, cechuje się długim cyklem wytwarzania i procesami, które nie występują w działalności pozarolniczej. 
Sprawia to, że prowadzenie ewidencji w gospodarstwach rolniczych wymaga w wielu przypadkach zastosowania odmiennych rozwiązań i pojęć. Problemy dotyczą zwłaszcza obrotowego inwentarza żywego oraz produkcji-niezakończonej. W tym żakresie w przedsiębiorstwach rolniczych stosuje się daleko idące uproszczenia, co należy uznać za rozwiązanie słuszne, ale do momentu, gdy nie zniekształca to w istotny sposób rzeczywistego obrazu ekonomicznego przedsiębiorstwa.

3. Sposób wyceny zapasów przyczynia się do istotnego kształtowania się znaczącej pozycji majątku gospodarstw, jakim są aktywa obrotowe. Zapasy wpływają zatem na ocenę struktury majątku przedsiębiorstwa, jak również na tzw. płynność ogólna, która informuje o możliwości spłaty bieżących zobowiązań. Gospodarkę zapasami w ujęciu organizacyjnym, jak również ewidencyjnym ułatwiłoby wprowadzenie zarządzania nimi według. koncepcji Just-in-Time, której istotnym założeniem jest znaczne ograniczenie poziomu zapasów.

\section{Literatura}

BERNACKI A., WASILEWSKI M., 1995: Wyniki produkcyjne i ekonomiczne gospodarstw rodzinnych prowadzących skomputeryzowaną rachunkowość „Rolin”. Postępy Nauk Rolniczych nr 4.

BERNACKI A., WASILEWSKI M., 1998: Ewidencja inwentarza żywego w gospodarstwie rolniczym. Rachunkowość nr 1.

BUK H., 2003: Problemy ustalenia wartości zapasu produktów na tle polskich i międzynarodowych standardów rachunkowości. Zeszyty Teoretyczne Rachunkowości, Numer Specjalny, Tom 13(69).

GORAJ L., MAŃKO S., SASS R., WYSZKOWSKA Z., 2004: Rachunkowość rolnicza. Difin, Warszawa.

MANTEUFFEL R., 1964: Rachunkowość rolnicza, tom I. PWRiL, Warszawa.

Międzynarodowe Standardy Sprawozdawczości Finansowej (MSSF) 2004, Tom I. International Accounting Standards Committee Foundation (IASCF).

WASILEWSKI M., 2003a: Standardy rachunkowości w rolnictwie na przykładzie MSR 41. Roczniki Naukowe Stowarzyszenia Ekonomistów Rolnictwa i Agrobiznesu, tom V, zeszyt 5.

WASILEWSKI M., 2003b: Sprawozdawczość finansowa w analizie wskaźnikowej gospodarstw rolniczych. [w:] Sprawozdawczość i rewizja finansowa w procesie podnoszenia kwalifikacji kadry menedżerskiej. Wydawnictwo AE w Krakowie, Kraków.

WASILEWSKI M., 2004: Ekonomiczno-organizacyjne uwarunkowania gospodarowania zapasami w przedsiębiorstwach rolniczych. Wydawnictwo SGGW, Warszawa.

Ustawa o podatku dochodowym od osób prawnych. DzU z 1992 r. Nr 21, poz. 86, tekst jednolity DzU z 2000 r. Nr 54, poz. 654 ze zm. 
Ustawa o rachunkowości z dnia 29 września 1994 r. Tekst jednolity DzU z 2002 r. Nr 76, poz. 694.

\title{
The issue of reserves according to the balance law and International Accounting Standard
}

\begin{abstract}
The paper presents accountant solutions concerning reserves according to the accountancy law and IAS-2 "Reserves" and IAS-41 "Agriculture". In accordance with the accountancy law accountants have to identify borne cost connected with run activity according to its usefulness, profitability and presenting information in the financial account. Solutions concerning recording and reserves valuation are strictly defined in the accountancy law, what is to a large extent coherent with solutions in IAS-2 "Reserves". Introducing IAS-41 "Agriculture" enabled to specify better solutions concerning reserves in agricultural farms. In that scope in agricultural enterprises far-reaching simplifications are applied. Reserves influence the assessment of the structure of firm's property, as well as the financial liquidity. The scope of recording of economic events connected with reserves could be limited and simplified by introducing reserves managing according to the conception "just in time".
\end{abstract}

